\title{
Review
}

\section{Difference in MSA Phenotype Distribution Between Populations: Genetics or Environment?}

\author{
Tetsutaro Ozawa ${ }^{\mathrm{a}, \mathrm{e}, \mathrm{f}, *}$, Tamas Revesz ${ }^{\mathrm{a}}$, Dominic Paviour ${ }^{\mathrm{a}, \mathrm{b}, \mathrm{c}}$, Andrew J. Lees ${ }^{\mathrm{b}, \mathrm{d}}$, Niall Quinn ${ }^{\mathrm{e}}$, \\ Mari Tada ${ }^{\mathrm{f}}$, Akiyoshi Kakita ${ }^{\mathrm{g}}$, Osamu Onodera ${ }^{\mathrm{h}}$, Koichi Wakabayashi ${ }^{\mathrm{i}}$, Hitoshi Takahashi ${ }^{\mathrm{g}}$, \\ Masatoyo Nishizawa ${ }^{\mathrm{f}}$ and Janice L. Holton ${ }^{\mathrm{a}}$ \\ ${ }^{a}$ Queen Square Brain Bank for Neurological Disorders, UCL Institute of Neurology, Queen Square, \\ University College London, London, UK \\ ${ }^{\mathrm{b}}$ The Sara Koe PSP Research Centre, Department of Molecular Neuroscience, UCL Institute of Neurology, \\ Queen Square, University College London, London, UK \\ ${ }^{\mathrm{c}}$ Dementia Research Centre, UCL Institute of Neurology, Queen Square, University College London, London, UK \\ ${ }^{\mathrm{d}}$ The Reta Lila Weston Institute of Neurological Sciences, Wakefield Street, UCL Institute of Neurology, \\ Queen Square, University College London, London, UK \\ ${ }^{\mathrm{e}}$ Sobell Department of Motor Neuroscience and Movement Disorders, UCL Institute of Neurology, \\ Queen Square, University College London, London, UK \\ ${ }_{\mathrm{f}}^{\mathrm{f}}$ Department of Neurology, Niigata University Brain Research Institute, Niigata, Japan \\ ${ }^{\mathrm{g}}$ Department of Pathology, Niigata University Brain Research Institute, Niigata, Japan \\ ${ }^{\mathrm{h}}$ Department of Molecular Neuroscience, Niigata University Brain Research Institute, Niigata, Japan \\ ${ }^{\mathrm{i}}$ Department of Neuropathology, Institute of Brain Science, Hirosaki University School of Medicine, Hirosaki, Japan
}

\begin{abstract}
The reasons for the differences in emphasis on striatonigral or olivopontocerebellar involvement in multiple system atrophy (MSA) remain to be determined. Semi-quantitative pathological analyses carried out in the United Kingdom and Japan demonstrated that olivopontocerebellar-predominant pathology was more frequent in Japanese MSA than British MSA. This observation provides evidence for a difference in phenotype distribution between British and Japanese patients with definite MSA. Studies of the natural history and epidemiology of MSA carried out in various populations have revealed that the relative prevalences of clinical subtypes of MSA probably differ among populations; the majority of MSA patients diagnosed in Europe have predominant parkinsonism (MSA-P), while the majority of MSA patients diagnosed in Asia have predominant cerebellar ataxia (MSA-C). Although potential drawbacks to the published frequencies of clinical subtypes and pathological subtypes should be considered because of selection biases, the difference demonstrated in pathological subtype is also consistent with the differences in clinical subtype of MSA demonstrated between Europe and Asia. Modest alterations in susceptibility factors may contribute to the difference in MSA phenotype distribution between populations. Synergistic interactions between genetic risk variants and environmental toxins responsible for parkinsonism or cerebellar dysfunction should therefore be explored. Further investigations are needed to determine the environmental, genetic, and epigenetic factors that account for the differences in clinicopathological phenotype of MSA among different populations.
\end{abstract}

Keywords: Multiple system atrophy, Parkinson's disease, spinocerebellar ataxia, genetic background, environmental factor

\footnotetext{
${ }^{*}$ Correspondence to: Tetsutaro Ozawa, Department of Neurology, Brain Research Institute, Niigata University, 1-757 Asahimachi, Chuo-ku, Niigata 951-8585, Japan. Tel.: +81 25227 0666; Fax: +81 25223 6646; E-mail: ozawa@ bri.niigata-u.ac.jp.
}

Multiple system atrophy (MSA) is a rare neurodegenerative disorder with both clinical (MSA with predominant parkinsonism: MSA-P versus MSA 
with predominant cerebellar ataxia: MSA-C) and pathological (striatonigral degeneration: SND versus olivopontocerebellar atrophy: OPCA) variants. Physicians and scientists investigating the aetiology of MSA have long been puzzled as to why some patients present primarily with parkinsonism whereas in others cerebellar ataxia predominates. MSA is characterized pathologically by glial (oligodendroglial) cytoplasmic inclusions (GCIs) [1, 2], which are composed of fibrillar $\alpha$-synuclein [3-5] and other proteins. Recently, genetic studies of single nucleotide polymorphisms (SNPs) demonstrated that certain SNPs in the $\alpha$ synuclein gene $(S N C A)$ were significantly associated with increased risk of developing MSA in European cohorts [6, 7]. The discovery of SNCA risk variants for MSA provided useful information which may be relevant to the mechanism underlying the $\alpha$-synuclein pathology in MSA. However, despite increased understanding of the pathological basis of MSA, the reasons for the differences in emphasis of striatonigral ( $\mathrm{StrN}$ ) or olivopontocerebellar (OPC) predominance in MSA remain to be determined. The natural history and epidemiology of MSA have been reported from many countries, and the variation in the phenotypic spectrum in different ethnic groups has recently attracted considerable attention.

The purpose of this review is to explore the factors that may underlie such phenotypic variation and to discuss any insights that these provide into the pathogenesis of MSA. We will summarize the results of neuropathological studies carried out in the United Kingdom (UK) [8] and Japan [9] which demonstrate that the spectrum of pathological involvement of the StrN and OPC systems differs between these two ethnically different populations and discuss the accumulating evidence that the relative clinical prevalences of MSA-P and MSA-C in Europe [10-17] may differ from those in Asia [18-21].

\section{COMPARATIVE STUDY OF MSA PATHOLOGY IN TWO LARGE PATIENT COHORTS}

In the past few years semi-quantitative pathological analyses of MSA have been carried out in the UK [8] and Japan [9] using autopsied brain material from 100 British (Caucasian) cases of MSA referred to the Queen Square Brain Bank, London, UK, and 50 cases of MSA referred to the Brain Research Institute, Niigata University, Japan. In this section, we summarize findings regarding MSA pathology that have been reported separately in two papers [8,9]. The first author (T.O.) of these studies performed semi-quantitative assessments of neuronal cell loss in 24 anatomical sites in the StrN and OPC regions (Fig. 1). For this, the following brain regions were selected for examination: (i) basal ganglia at the level of the nucleus accumbens and the anterior commissure; (ii) midbrain at the level of the red nucleus and also at the decussation of superior cerebellar peduncle; (iii) cerebellar vermis and hemisphere at the level of the dentate nucleus; (iv) rostral pons at the level of the locus coeruleus and caudal pons; and (v) medulla oblongata [8]. The semi-quantitative assessments of neuronal cell loss were performed using sections stained by haematoxylin and eosin (H\&E) and Luxol fast blue/cresyl violet, and assigned one of four scores for the degree of neuronal loss $(0,1+, 2+$, or $3+)$ in each anatomical site. There was a trend for the British cases to feature greater involvement of the basal ganglia, while in the Japanese cases the OPC region tended to be more severely affected than StrN structures (Fig. 2). The substantia nigra was found to be equally vulnerable in both the British and the Japanese MSA cases. Based on the data of the semi-quantitative assessments, the grading scale used to characterize StrN pathology was as follows. Grade 1: the $\mathrm{SbN}$ demonstrates $1+$ or $2+$ neuronal cell loss, and there is 0 or $1+$ neuronal cell loss in globus pallidus, caudate nucleus or putamen. Grade 2: the $\mathrm{SbN}$ and putamen demonstrate $2+$ or $3+$ neuronal cell loss, and there is $1+$ or $2+$ neuronal cell loss in the caudate nucleus and globus pallidus (except for cases with $3+$ neuronal cell loss in both $\mathrm{SbN}$ and putamen). Grade 3: the $\mathrm{SbN}$ and putamen demonstrate $3+$ neuronal cell loss. The grading scale used to characterize OPC pathology was as follows. Grade 1: in the inferior olivary nucleus, pontine nuclei, cerebellar hemisphere or vermis, there is 0 or $1+$ neuronal cell loss or one structure demonstrating $2+$ neuronal cell loss, while the others have less than $1+$ neuronal cell loss. Grade 2: in the inferior olivary nucleus, pontine nuclei, cerebellar hemisphere or vermis, there is either $2+$ neuronal cell loss or one structure demonstrating $3+$ neuronal cell loss, while the others have less than $2+$ neuronal cell loss. Grade 3 : more than two structures among the inferior olivary nucleus, pontine nuclei, cerebellar hemisphere or vermis demonstrate $3+$ neuronal cell loss, If there were different degrees of pathology in the same structure (e.g., rostral pons $1+$, caudal pons $3+$ ), the worst (e.g., $3+$ ) was used for the grading. Combinations of scores reflecting the grading for StrN and OPC neuronal loss were allotted to three categories: "StrN-predominant pathology", "OPC-predominant pathology", and "StrN and 


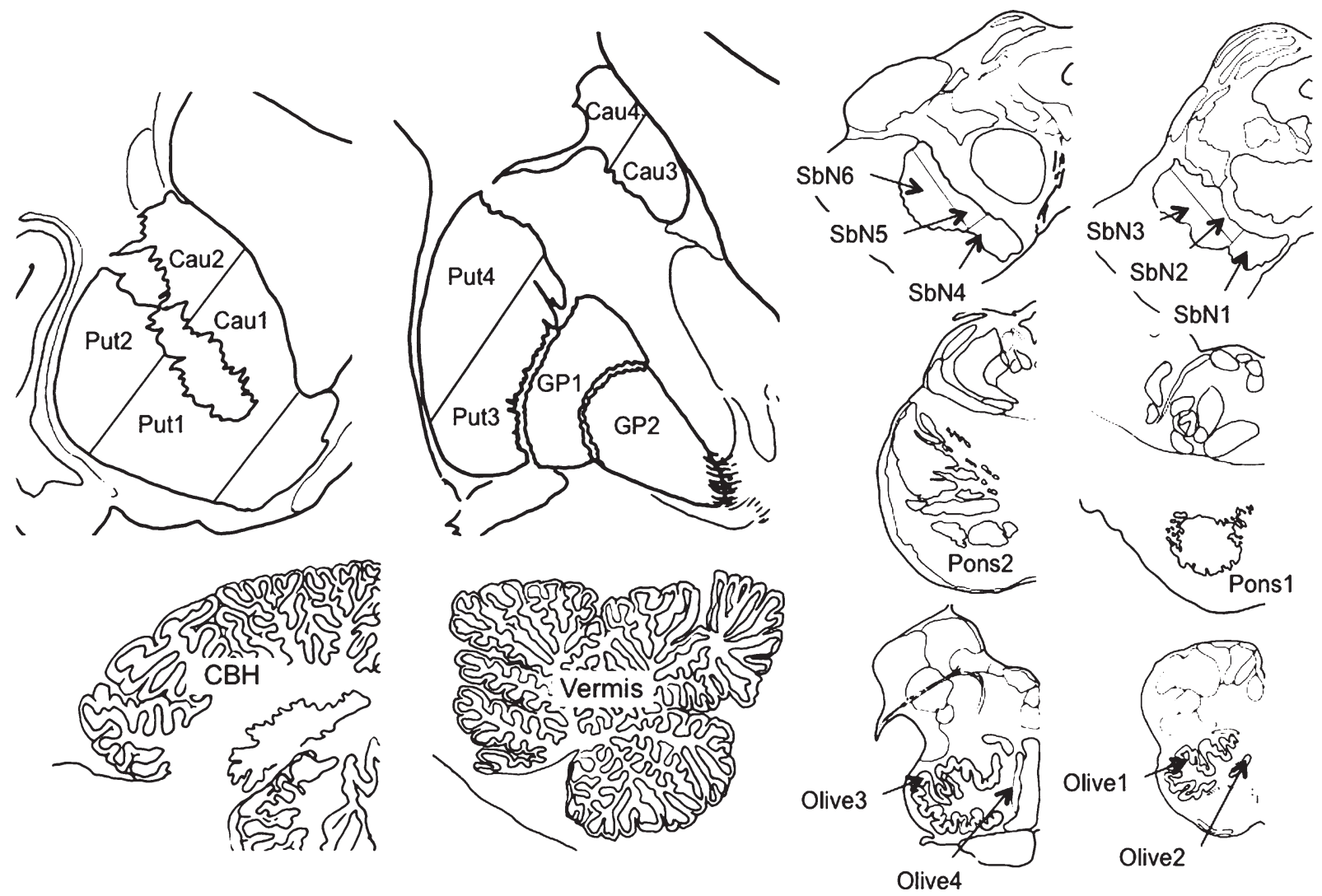

Fig. 1. The 24 anatomical sites in the striatonigral and olivopontocerebellar regions examined in a comparison of two large patient cohorts $[8,9]$. Semi-quantitative assessment of neuronal loss in these anatomical regions was performed in autopsied brain samples from 100 British patients and 50 Japanese patients with multiple system atrophy. Put = putamen, $\mathrm{Cau}=$ caudate nucleus, $\mathrm{GP}=\mathrm{globus}$ pallidus, $\mathrm{SbN}=$ substantia nigra, $\mathrm{CBH}=$ cerebellar hemisphere.

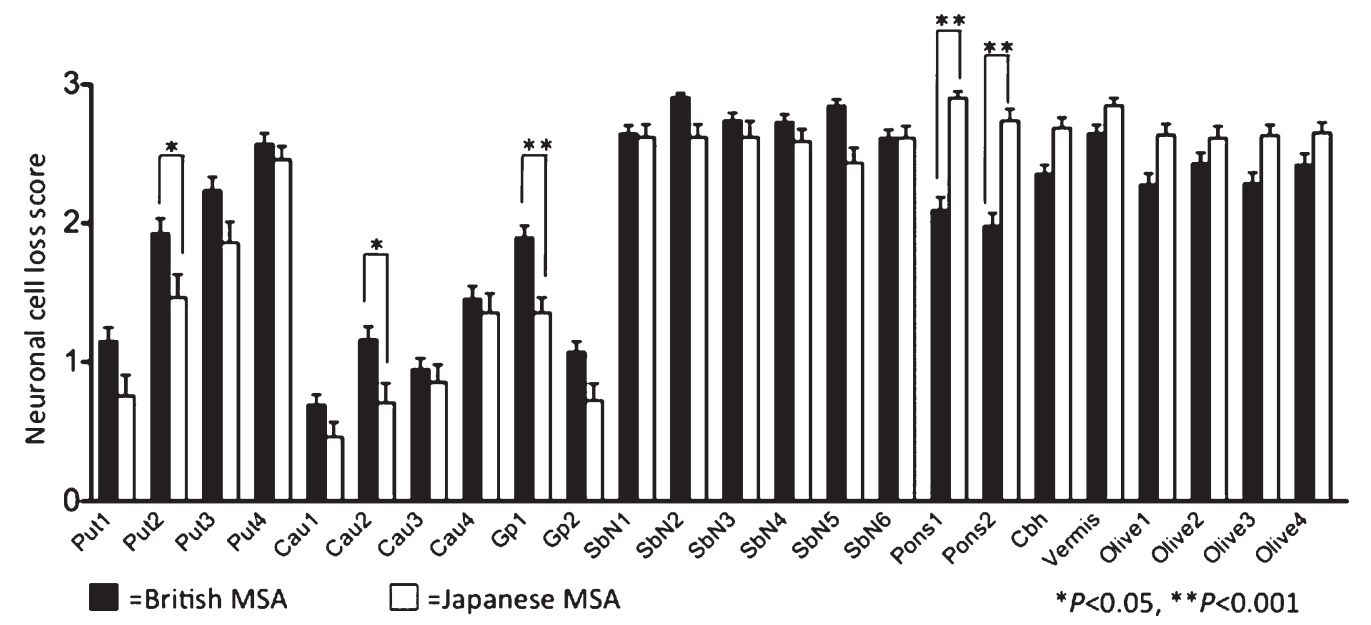

Fig. 2. Summary of the results of a comparative study of multiple system atrophy (MSA) cohorts carried out in the UK and Japan, which were presented separately in two papers $[8,9]$. British MSA patients have significantly higher scores for neuronal loss in Put2, Cau2 and GP1 than do Japanese patients $(P<0.05$, Bonferroni corrected). In Pons 1 and 2, Japanese MSA patients have significantly higher scores for neuronal loss than British patients $(P<0.001$, Bonferroni corrected). Generally, British MSA cases tended to feature greater involvement of the basal ganglia, while Japanese cases tended to feature greater involvement of the olivopontocerebellar region. The substantia nigra is equally vulnerable in both British and Japanese patients with MSA. Put = putamen, Cau = caudate nucleus, GP= globus pallidus, $\mathrm{SbN}=$ substantia nigra, Cbh $=$ cerebellar hemisphere. Data are represented as mean \pm standard error of the mean. 

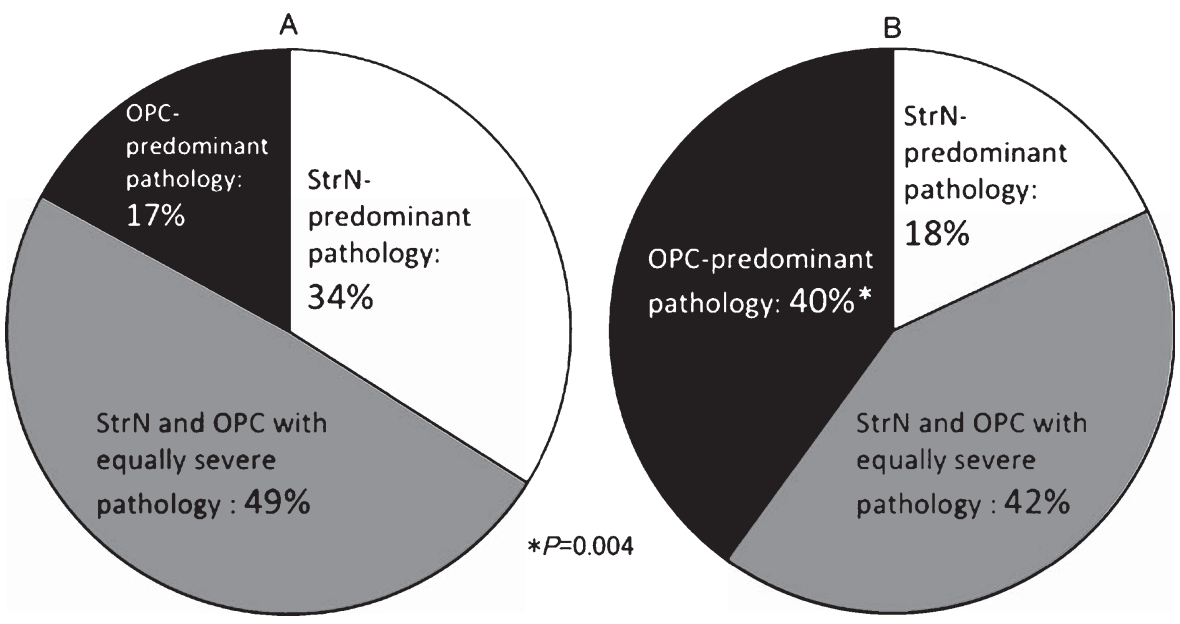

Fig. 3. Relative prevalence of striatonigral (StrN)- and olivopontocerebellar (OPC)-predominant pathology in British and Japanese multiple system atrophy (MSA), as presented separately in two papers [8, 9]. (A) In the British MSA cohort, the relative prevalence of pathological phenotypes was as follows: $17 \%$ had OPC-predominant, 34\% StrN-predominant, and the remainder (49\%) equivalent pathology. (B) In the Japanese cohort, $40 \%$ of cases had OPC-predominant pathology, 18\% StrN-predominant pathology, and the remainder (42\%) had equivalent pathology. The frequency of OPC-predominant pathology in the Japanese series was significantly higher than in the British series $(P=0.004$, Fisher's exact test).

OPC with equally severe pathology" [8]. In the British MSA cohort the relative prevalence of these phenotypes was as follows: $17 \%$ of cases had OPCpredominant pathology, 34\% had StrN-predominant pathology, and the remainder (49\%) had StrN and OPC with equally severe pathology (Fig. 3A) [8]. In the Japanese cohort, $40 \%$ of cases had OPC-predominant pathology, $18 \%$ had StrN-predominant pathology, and the remainder (42\%) had equally severe StrN and OPC pathology (Fig. 3B) [9]. Thus the occurrence of OPCpredominant pathology in the Japanese series was significantly higher than that in the British series [9].

With regard to the clinicopathological correlations observed in the two studies, analyses of parkinsonism and cerebellar dysfunction demonstrated a reasonable correlation between clinical findings and neuropathology in both StrN- and OPC-predominant cases [8,9]. Initial symptoms were quite variable in the patients with "StrN and OPC with equally severe pathology" groups [9], indicating that the clinical diagnoses of patients in this category include a mixture of MSA-P and MSA-C.

\section{FREQUENCY OF LEWY BODY PATHOLOGY IN CAUCASIAN AND JAPANESE MSA}

Lewy bodies have been identified in $8-12 \%$ of brains of normal individuals over age 60 years; this condition is often termed incidental Lewy body disease and is thought to represent presymptomatic Parkinson's disease (PD) [22-24]. Only a few studies have examined the frequency of Lewy bodies in patients with MSA. Wenning and colleagues found that 3 of 35 MSA cases (8.5\%) had Lewy bodies in cerebral cortex and substantia nigra [25]. Jellinger reported that 10 of 44 MSA cases (23\%) had Lewy bodies mainly in the brainstem [26]. Ozawa and colleagues reported that 10 of 94 cases $(10.6 \%)$ had Lewy bodies in the substantia nigra or the dorsal motor nucleus of the vagus [8]. All of these studies involved Caucasian cases. Regarding the frequency of Lewy bodies in Japanese cases of MSA, Ozawa and colleagues did not find Lewy bodies in the substantia nigra or the dorsal motor nucleus of the vagus in any of their 50 MSA cases [9]. However, Sone and colleagues reported that 4 of 26 MSA cases (15\%) had a few Lewy bodies in the substantia nigra and the dorsal motor nucleus of the vagus [27]. Whilst it is of interest to compare the frequency of Lewy body pathology in MSA among various populations, there are some difficulties with investigating Lewy body pathology in MSA brains. Thus it can be difficult to differentiate Lewy bodies from $\alpha$-synuclein-positive neuronal cytoplasmic inclusions (NCIs) [27], which have been described in the substantia nigra in MSA [28]. Also, as Lewy bodies occur in various anatomical sites the sampling strategy employed may influence their detection. In the context of MSA there are no guidelines for the diagnosis of concomitant PD or incidental Lewy body 
Table 1

The relative frequencies of MSA-P and MSA-C in various populations

\begin{tabular}{|c|c|c|c|c|c|c|c|}
\hline Author & Year & $\begin{array}{l}\text { Population or } \\
\text { regional study } \\
\text { group }\end{array}$ & $\begin{array}{l}\text { Total number } \\
\text { of cases }\end{array}$ & $\begin{array}{l}\text { Number of } \\
\text { MSA-P (\%) }\end{array}$ & $\begin{array}{l}\text { Number of } \\
\text { MSA-C }(\%)\end{array}$ & Notes & $\begin{array}{c}\text { Ref } \\
\text { no }\end{array}$ \\
\hline $\begin{array}{l}\text { Wenning, } \\
\text { et al. }\end{array}$ & 1994 & United Kingdom & 100 & $82(82)$ & $18(18)$ & $\begin{array}{l}\text { The research center was located } \\
\text { in London }\end{array}$ & 13 \\
\hline Testa, et al. & 1996 & Italy & 59 & $34(57.6)$ & $25(42.4)$ & $\begin{array}{l}\text { The research center was located } \\
\text { in Milan }\end{array}$ & 12 \\
\hline $\begin{array}{l}\text { Watanabe, } \\
\text { et al. }\end{array}$ & 2002 & Japan & 230 & $75(32.6)$ & $155(67.4)$ & $\begin{array}{l}\text { The research center was located } \\
\text { in Nagoya }\end{array}$ & 19 \\
\hline $\begin{array}{l}\text { Chrysostome, } \\
\text { et al. }\end{array}$ & 2004 & France & 50 & $35(70)$ & $15(30)$ & $\begin{array}{l}\text { The research center was located } \\
\text { in Bordeaux }\end{array}$ & 16 \\
\hline $\begin{array}{l}\text { Benrud- } \\
\text { Larson, } \\
\text { et al. }\end{array}$ & 2005 & United States & 99 & $62(63)$ & $25(26)$ & $\begin{array}{l}\text { Remaining } 11 \text { cases had equally } \\
\text { severe findings of MSA-P and } \\
\text { MSA-C. Racial breakdown was } \\
96 \% \text { Caucasian, 3\% Asian/Pacific } \\
\text { Islander, and } 1 \% \\
\text { African-American }\end{array}$ & 15 \\
\hline Yabe, et al. & 2006 & Japan & 142 & $23(16.2)$ & $119(83.8)$ & $\begin{array}{l}\text { The research center was located } \\
\text { in Sapporo }\end{array}$ & 18 \\
\hline May, et al. & 2007 & $\begin{array}{l}\text { North American } \\
\text { MSA Study } \\
\text { Group }\end{array}$ & 67 & (60) & (13) & $\begin{array}{l}\text { The remaining cases }(27 \%) \text { had } \\
\text { equally severe findings of MSA-P } \\
\text { and MSA-C. The majority was } \\
\text { non-Hispanic Caucasian }\end{array}$ & 14 \\
\hline $\begin{array}{l}\text { Kollensperger, } \\
\text { et al. }\end{array}$ & 2010 & $\begin{array}{c}\text { European MSA } \\
\text { Study Group }\end{array}$ & 437 & $298(68.2)$ & $139(31.8)$ & $\begin{array}{l}\text { This study involved } 19 \text { research } \\
\text { centers in } 10 \text { countries (Germany, } \\
\text { Austria, France, UK, Portugal, } \\
\text { Spain, Italy, Sweden, Denmark, } \\
\text { and Israel) Spanish data revealed } \\
68 \% \text { MSA-C }\end{array}$ & 11 \\
\hline Seo, et al. & 2010 & South Korea & 100 & $27(27)$ & $73(73)$ & $\begin{array}{l}\text { The research center was located } \\
\text { in Seoul }\end{array}$ & 20 \\
\hline
\end{tabular}

disease. Thus, determining clinicopathological correlations of Lewy body pathology in MSA cases remains problematic.

\section{DISTRIBUTION OF PATIENTS WITH MSA-P AND MSA-C IN VARIOUS POPULATIONS}

We have reviewed articles detailing the natural history or epidemiology of MSA to determine the relative frequencies of MSA-P and MSA-C in various populations (Table 1). Studies with more than 50 patients with possible or probable MSA performed since the publication of the original Quinn diagnostic criteria [29], which analyzed the relative frequencies of MSA-P and MSA-C, were reviewed. Where more than 2 articles were published by the same group, the most recent publication was included. In Wenning and colleagues' study of 100 British patients with clinical MSA, $82 \%$ were MSA-P and $18 \%$ were MSA-C [13]. The interim report from the European MSA Study Group (EMSA-SG) involving research groups in 11 countries (Germany, Austria, France, UK, Portugal, Spain, Italy, Sweden, Denmark, Slovenia and Israel) described 412 European patients with MSA had been entered into the registry by 2004 , $63 \%$ of these patients were diagnosed with MSA$\mathrm{P}$ and $34 \%$ with MSA-C, while the remaining cases (3\%) did not meet criteria for MSA [10]. The final report from the EMSA-SG involving 437 MSA patients confirmed that the majority of patients exhibited MSA$\mathrm{P}(68 \%)$; however, the Spanish group reported $69 \%$ MSA-C, probably due to the large number of cases emanating from the group of Berciano et al. in Santander that has a special interest in cerebellar disorders [11]. In Milan in Italy, Testa and colleagues studied 59 patients with MSA, including 34 (57.6\%) with MSA-P and 25 (42.4\%) with MSA-C [12]. Chrysostome and colleagues, studying 50 French patients with MSA, found that 35 (70\%) had MSA-P and $15(30 \%)$ had MSA-C [16]. In the United States, Benrud-Larson and colleagues reported that among 99 patients with MSA, 62 (63\%) had MSA-P and 25 (26\%) MSA-C -the remaining patients had equally severe findings of MSA-P and MSA-C ("equivalent" 
MSA) [15]. The North American MSA Study Group (NAMSA-SG) enrolled 67 patients with MSA (the majority of patients were non-Hispanic Caucasian), and found that $60 \%$ were diagnosed with MSA-P and $13 \%$ with MSA-C, while the remaining patients (27\%) had "equivalent" MSA [14]. Yabe and colleagues, studying 142 Japanese patients with MSA from the northern island of Japan, included $119(83.8 \%)$ cases of MSA-C and 23 (16.2\%) of MSA-P [18]. From the main island of Japan, Watanabe and colleagues enrolled 230 Japanese patients with MSA, 155 (67.4\%) of whom had MSA-C and 75 (32.6\%) had MSA$P$ [19]. In Korea Seo and colleagues, studying 100 Korean patients with MSA, noted that MSA-C patients accounted for $73 \%$ of their cohort [20]. There are some studies with fewer than 50 MSA patients that nevertheless should be mentioned in this review. A Singaporean study involving 33 cases [21], the only study from South East Asia, revealed that MSA-C patients accounted for $67 \%$ of the cohort. A study from a centre in Germany with a special interest in cerebellar disorders enrolled 32 patients that included 11 (34.4\%) patients with MSA-P and 21 (64.6\%) patients with MSA-C [17]. In summary, in studies from Asia, the majority of patients exhibited features of MSA-C, whereas in studies from Europe and North America MSA-P patients predominated; however, there are a few isolated studies presenting contrasting results. As suggested above, published frequencies of MSA-P and MSA-C are influenced by selection biases determined by the clinical interest of the investigators in either parkinsonism or cerebellar dysfunction. Nevertheless, the comparative study of MSA pathology in two large patient cohorts mentioned above $[8,9]$ demonstrated that OPC-predominant pathology seems to be more frequent in Japanese MSA than British MSA, and this finding is consistent with the trend that MSA-C patients are more frequent in Asian populations (East and Southeast Asian countries) than in European populations (of Europe and North America). This points to the need for further investigation to elucidate biological factors determining this regional difference in distribution of clinicopathological phenotypes of MSA.

Given the difference demonstrated in clinical subtype of MSA between Europe and Asia, its treatment also presumably differs between Europe and Asia. In Europe, the majority of patients presenting with MSA-P indicates the importance of treatment of parkinsonism, while in Asia, with the majority of patients presenting with MSA-C, management of cerebellar dysfunction may be more important.

\section{DO GENETIC RISK VARIANTS FOR MSA DIFFER BETWEEN POPULATIONS?}

\author{
$\alpha$-synuclein gene (SNCA)
}

The neuropatholgical hallmark of MSA is the GCI associated with neuronal cell loss in brain regions involved in motor and preganglionic autonomic control [30]. The major protein component of the GCI is insoluble, fibrillar $\alpha$-synuclein hence MSA is recognized as a member of the group of $\alpha$-synucleinopathies, which also includes PD and dementia with Lewy bodies [31]. Previous studies including sequencing of the SNCA coding sequence, gene dosage measurements, and microsatellite testing have failed to identify significant associations of $S N C A$ variants with MSA [32-34]. SNCA expression studies did not detect altered gene expression levels in MSA brains [35-37]. Furthermore, a haplotype study by Ozawa and colleagues using single nucleotide polymorphism (SNP) failed to demonstrate any association with MSA [38]; this negative finding might be explained by the fact that the SNPs selected for examination were limited and therefore unable to detect $S N C A$ risk variants for MSA. Recently, Scholz and colleagues found increased risk for MSA associated with SNCA variants in Caucasian MSA patients [6]. They reported that the SNPs rs11931074 and 3857059 in SNCA, originally identified in a genome-wide association study of PD, exhibited highly significant associations with increased risk of development of MSA. The finding for SNP rs11931074 was subsequently replicated in an independent set of autopsy-proven cases of MSA from the Mayo Clinic in Jacksonville [39]. However, whether SNPs rs11931074 and 3857059 in SNCA contribute to the diversity of clinical subtypes including MSA-P and MSA-C remains to be elucidated. AlChalabi and colleagues found another two positive associations in the SNCA gene with Caucasian patients with MSA, one with rs3822086 and the other with rs3775444 [7]. Interestingly, the association between MSA-C and these two SNPs was strong despite the small number of MSA-C cases in their cohort [7]. It would be of interest to examine whether these two SNPs of SNCA are also associated with increased risk of MSA in Asian cohorts, which feature a high prevalence of MSA-C patients.

Although genetic variants of SNCA have been found in Caucasian patients to be associated with MSA, this finding has not been replicated in Asian patients with MSA. Yun and colleagues, seeking an association between SNP rs11931074 and possible or probable 
MSA in Korean patients $(n=100)$, could not replicate the results previously reported in Caucasian patients [40]. They observed that the inconsistent results regarding the association between SNP rs11931074 and risk for MSA could be related to the fact that the frequency of risk allele $\mathrm{T}$ of rs 11931074 is low (2 to $10 \%$ ) in European populations but very high (51 to $58 \%$ ) in Asian populations [40]. It is tempting to speculate that the SNCA risk variants for MSA contribute to the disequilibrium in MSA phenotype distribution between populations. If this is the case, the broad range of variation in risk-allele frequencies in different populations should be carefully reviewed.

Duplication or triplication of $S N C A$ has been identified in families with parkinsonism [41-43]. Gwinn-Hardy and colleagues performed neuropathological investigation on an individual from the family with parkinsonism, in which the SNCA triplication was subsequently identified [44]. This patient had striking alpha-synuclein pathology characterized by numerous Lewy bodies in the brainstem and cerebral cortices, but also widespread GCIs in the cerebral and cerebellar white matter [44]. In cases of $S N C A$ duplication, alpha-synuclein positive GCIs have also been found in substantia nigra and other CNS regions [45]. These observations emphasise that further investigations are required to determine whether altered expression of SNCA contributes to the pathogenesis of MSA.

\section{Genes responsible for spinocerebellar ataxia}

Patients with dominantly inherited spinocerebellar ataxia (SCA) have been reported to occasionally exhibit parkinsonism [46-49], autonomic failure [50, 51], and other non-motor symptoms [52, 53], clinical features similar to those seen in MSA. Furthermore, neuropathological examination demonstrated that a few cases of SCA1 [54], SCA2 [55, 56] and SCA3 [57] had inclusions resembling GCIs. The nature of the glial inclusion in the patient with SCA1 remains uncertain as immunohistochemical profile for $\alpha$-synuclein was not available [54]. The two cases of SCA2 were reported to have ubiquitin-positive, $\alpha$-synuclein-negative glial inclusions indicating that although there is some morphological resemblance, these inclusions should be considered as different from the GCIs of MSA [55, 56]. In the reported case of SCA 3 the pathological changes were found to be typical of MSA including $\alpha$-synuclein immunoreactive GCIs and it was considered likely that this was a case of MSA with concomitant SCA3 expansion, although it does raise the possibility that SCA3 expansion may be a risk factor for MSA [57]. Considering the phenotypic diversity of MSA, it should be noted that the relative prevalence of SCA genotypes also differs between Caucasian and Japanese patients; SCA1 and SCA2 are more prevalent in Caucasians, whereas SCA3, SCA6, and dentatorubral pallidoluysian atrophy (DRPLA) are more prevalent in the Japanese population [58]. Interestingly, the frequency of normal alleles with relatively large numbers of CAG repeats is also associated with the prevalence of these SCA genotypes [58]. In this regard, further study is needed to determine whether normal alleles with a relatively large number of CAG repeats in SCA genes have any relationship to the pathogenesis or phenotype of MSA.

\section{Other genes related to neurodegeneration or inflammation}

Previous studies have failed to identify significant associations between MSA and other genes implicated in neurodegenerative diseases such as those for apolipoprotein $\mathrm{E}[33,59,60]$, dopamine beta-hydroxylase [61, 62], ubiquitin C-terminal hydrolase-1(UCHL1) [63], fragile X mental retardation 1 [64-67], and leucine-rich kinase 2 (LRKK2) $[68,69]$. Mutations in the glucocerebrosidase gene coding for lysosomal beta-glucocerebrosidase have recently been found to be a risk factor for PD and dementia with Lewy bodies [70-76]; however, these mutations have not been found in patients with MSA [77, 78]. Recently, a mutational screening study of parkin and PINK1 has been performed in 87 pathologically proven MSA cases, but the frequencies of the possibly pathogenic variants were not significantly different from control data [79]. Thus any relationship between the genes mentioned above and MSA phenotypic diversity appears to be unlikely. Regarding the tau gene (MAPT) and MSA, haplotype analyses had failed to identify any association between $M A P T$ and MSA [33, 60]; however, a recent study involving 61 cases of pathologically confirmed MSA demonstrated that the frequency of SNP rs 1052553 in MAPT, which corresponded to $\mathrm{H} 1$ haplotype, was significantly increased in MSA cases [80]. In this regard, it is important to determine whether this finding is replicated in Asian patients with MSA, because the frequency of A0 allele in $\mathrm{H} 1$ haplotype in Japanese population was reported to be very high $(98.5 \%$ in control subjects) [81]. Whether MAPT H1 haplotype contributes MSA phenotypic diversity remains to be elucidated. 
Several studies of the genes responsible for inflammatory processes indicated that polymorphisms of interleukin-1A [82], interleukin-1B [83], interleukin-8 [84], and intercellular adhesion molecule-1 genes [84] were associated with increased risk of MSA. Another study demonstrated an association between polymorphism of the alpha-1-antichymotrypsin gene and risk of MSA [85]. Promoter region polymorphism in the tumor necrosis factor gene has also been reported to be associated with increased risk of MSA [86]. However, whether variants of these genes may contribute to phenotypic diversity in MSA has not been investigated.

\section{ARE ENVIRONMENTAL FACTORS RESPONSIBLE FOR THE DIVERSITY OF MSA PHENOTYPE?}

\section{Environmental toxins associated with parkinsonism or cerebellar dysfunction}

Accumulating evidence indicates that the prevalence of PD in Asian countries is slightly lower than that in Western countries [87, 88]. Professional exposure to some pesticides (e.g., organochlorine insecticides) has been reported to be associated with PD $[89,90]$. In this regard, it is tempting to speculate that agricultural use of pesticides might also differ between Asian and Western countries. Further studies are needed to determine differences in the pattern of pesticide use between Asian and Western countries. For patients with MSA, the relationship between exposure to pesticides and increased risk of MSA has been controversial [16, 91-93], and whether exposure to pesticides modifies the MSA phenotype is unclear.

Given the finding that MSA-C is more frequent than MSA-P in Asian populations, environmental exposures related to cerebellar dysfunction should be carefully reviewed. Recently, beta-fluoroethyl acetate (ethyl fluoroacetate, FEA), a highly potent toxic chemical that has been used against rats and wild animals, was reported to cause selective cerebellar dysfunction [94]. This is a unique finding reported from South Korea. In South Korea, FEA had been available to the general public as an effective pest control agent with less than optimal regulation until 2005 [94]. In Japan, FEA has been designated as a Type II Monitoring Chemical Substance, indicating that the use of this compound is under government surveillance. On the whole, FEA is banned or severely restricted in most countries, and so cases of FEA poisoning are very rare [94]. Whether FEA is likely to be an environmental toxin in South Korea and Japan warrants further investigation.

\section{Perspective on the interaction between environmental toxins and genetic risk variants}

Brighina and colleagues tested possible joint effects of pesticide exposures and SNCA variants (REP1 genotypes) on risk of PD, and found that both SNCA REP1 score and pesticide exposure were significantly associated with PD in younger subjects, though no pairwise interactions were detected [95]. The synergistic interaction between genetic risk variants and environmental toxins may be important when considering the reasons for the differences in emphasis on StrN or OPC involvement in MSA. Further study is needed to determine epigenetic factors in the phenotypic diversity of MSA.

\section{CONCLUSION}

Comparative study of MSA pathology with an identical methodological approach in two large patient cohorts (one British, one Japanese) demonstrated a difference in the distribution of phenotypes between the two populations. The frequent observation of OPCpredominant pathology in Japanese cases of MSA is in keeping with previous findings that the majority of Asian patients exhibit MSA-C. These observations raise the possibility that different populations may have different disease susceptibility factors for MSA. Although genetic variants of SNCA have been found to be associated with MSA in Caucasian patients, this finding has not been replicated in Korean patients with MSA. It is tempting to speculate that SNCA risk variants for MSA may contribute to the difference in MSA phenotype distribution among populations; thus, the broad range of risk-allele frequencies in different populations should be carefully reviewed. In the case of environmental factors, the relationship between exposure to pesticides and increase in risk of MSA has been controversial, and whether exposure to pesticides modifies MSA phenotype remains unclear. Nevertheless, the synergistic interaction between SNCA variants and some environmental toxins could play a role in the pathogenesis and phenotypic diversity of MSA. Further investigation is needed to determine the environmental, genetic and epigenetic factors that account for the differences demonstrated in the 
clinicopathological phenotype of MSA in different populations.

\section{REFERENCES}

[1] Papp MI, Kahn JE, \& Lantos PL (1989) Glial cytoplasmic inclusions in the CNS of patients with multiple system atrophy (striatonigral degeneration, olivopontocerebellar atrophy and Shy-Drager syndrome). J Neurol Sci, 94, 79-100.

[2] Nakazato Y, Yamazaki H, Hirato J, Ishida Y, \& Yamaguchi H (1990) Oligodendroglial microtubular tangles in olivopontocerebellar atrophy. J Neuropathol Exp Neurol, 49, 521-530.

[3] Wakabayashi K, Yoshimoto M, Tsuji S, \& Takahashi H (1998) Alpha-synuclein immunoreactivity in glial cytoplasmic inclusions in multiple system atrophy. Neurosci Lett, 249, 180-182.

[4] Mezey E, Dehejia A, Harta G, Papp MI, Polymeropoulos MH, \& Brownstein MJ (1998) Alpha synuclein in neurodegenerative disorders: Murderer or accomplice? Nat Med, 4 755-757.

[5] Goedert M, \& Spillantini MG (1998) Lewy body diseases and multiple system atrophy as alpha-synucleinopathies. Mol Psychiatry, 3, 462-465.

[6] Scholz SW, Houlden H, Schulte C, Sharma M, Li A, Berg D, Melchers A, Paudel R, Gibbs JR, Simon-Sanchez J, PaisanRuiz C, Bras J, Ding J, Chen H, Traynor BJ, Arepalli S, Zonozi RR, Revesz T, Holton J, Wood N, Lees A, Oertel W, Wullner U, Goldwurm S, Pellecchia MT, Illig T, Riess O, Fernandez HH, Rodriguez RL, Okun MS, Poewe W, Wenning GK, Hardy JA, Singleton AB, Gasser T, Del Sorbo F, Schneider S, \& Bhatia KP (2009) SNCA variants are associated with increased risk for multiple system atrophy. Ann Neurol, 65, 610-614.

[7] Al-Chalabi A, Durr A, Wood NW, Parkinson MH, Camuzat A, Hulot JS, Morrison KE, Renton A, Sussmuth SD, Landwehrmeyer BG, Ludolph A, Agid Y, Brice A, Leigh PN, \& Bensimon G (2009) Genetic variants of the alphasynuclein gene SNCA are associated with multiple system atrophy. PLoS One, 4, e7114.

[8] Ozawa T, Paviour D, Quinn NP, Josephs KA, Sangha H, Kilford L, Healy DG, Wood NW, Lees AJ, Holton JL, \& Revesz T (2004) The spectrum of pathological involvement of the striatonigral and olivopontocerebellar systems in multiple system atrophy: Clinicopathological correlations. Brain, 127, 2657-2671.

[9] Ozawa T, Tada M, Kakita A, Onodera O, Ishihara T, Morita T, Shimohata T, Wakabayashi K, Takahashi H, \& Nishizawa M (2010) The phenotype spectrum of Japanese multiple system atrophy. J Neurol Neurosurg Psychiatry, 81, 12531255.

[10] Geser F, Seppi K, Stampfer-Kountchev M, Kollensperger M, Diem A, Ndayisaba JP, Ostergaard K, Dupont E, Cardozo A, Tolosa E, Abele M, Dodel R, Klockgether T, Ghorayeb I, Yekhlef F, Tison F, Daniels C, Kopper F, Deuschl G, Coelho M, Ferreira J, Rosa MM, Sampaio C, Bozi M, Schrag A, Hooker J, Kim H, Scaravilli T, Mathias CJ, Fowler C, Wood N, Quinn N, Widner H, Nilsson CF, Lindvall O, Schimke N, Eggert KM, Oertel W, del Sorbo F, Carella F, Albanese A, Pellecchia MT, Barone P, Djaldetti R, Meco G, Colosimo C, Gonzalez-Mandly A, Berciano J, Gurevich T, Giladi N, Galitzky M, Ory F, Rascol O, Kamm C, Buerk K, Maass S, Gasser T, Poewe W, \& Wenning GK (2005) The European Multiple System Atrophy-Study Group (EMSA-SG). J Neural Transm, 112, 1677-1686
[11] Kollensperger M, Geser F, Ndayisaba JP, Boesch S, Seppi K, Ostergaard K, Dupont E, Cardozo A, Tolosa E, Abele M, Klockgether T, Yekhlef F, Tison F, Daniels C, Deuschl G, Coelho M, Sampaio C, Bozi M, Quinn N, Schrag A, Mathias CJ, Fowler C, Nilsson CF, Widner H, Schimke N, Oertel W, Del Sorbo F, Albanese A, Pellecchia MT, Barone P, Djaldetti R, Colosimo C, Meco G, Gonzalez-Mandly A, Berciano J, Gurevich T, Giladi N, Galitzky M, Rascol O, Kamm C, Gasser T, Siebert U, Poewe W, \& Wenning GK (2010) Presentation, diagnosis, and management of multiple system atrophy in Europe: Final analysis of the European multiple system atrophy registry. Mov Disord, 25, 2604-2612.

[12] Testa D, Filippini G, Farinotti M, Palazzini E, \& Caraceni T (1996) Survival in multiple system atrophy: A study of prognostic factors in 59 cases. J Neurol, 243, 401-404.

[13] Wenning GK, Ben Shlomo Y, Magalhaes M, Daniel SE, \& Quinn NP (1994) Clinical features and natural history of multiple system atrophy. An analysis of 100 cases. Brain, 117(Pt 4), 835-845.

[14] May S, Gilman S, Sowell BB, Thomas RG, Stern MB, Colcher A, Tanner CM, Huang N, Novak P, Reich SG, Jankovic J, Ondo WG, Low PA, Sandroni P, Lipp A, Marshall FJ, Wooten F, \& Shults CW (2007) Potential outcome measures and trial design issues for multiple system atrophy. Mov Disord, 22, 2371-2377.

[15] Benrud-Larson LM, Sandroni P, Schrag A, \& Low PA (2005) Depressive symptoms and life satisfaction in patients with multiple system atrophy. Mov Disord, 20, 951-957.

[16] Chrysostome V, Tison F, Yekhlef F, Sourgen C, Baldi I, \& Dartigues JF (2004) Epidemiology of multiple system atrophy: A prevalence and pilot risk factor study in Aquitaine, France. Neuroepidemiology, 23, 201-208.

[17] Schulz JB, Klockgether T, Petersen D, Jauch M, MullerSchauenburg W, Spieker S, Voigt K, \& Dichgans J (1994) Multiple system atrophy: Natural history, MRI morphology, and dopamine receptor imaging with 123IBZM-SPECT. J Neurol Neurosurg Psychiatry, 57, 1047-1056.

[18] Yabe I, Soma H, Takei A, Fujiki N, Yanagihara T, \& Sasaki $\mathrm{H}$ (2006) MSA-C is the predominant clinical phenotype of MSA in Japan: Analysis of 142 patients with probable MSA. J Neurol Sci, 249, 115-121.

[19] Watanabe H, Saito Y, Terao S, Ando T, Kachi T, Mukai E, Aiba I, Abe Y, Tamakoshi A, Doyu M, Hirayama M, \& Sobue G (2002) Progression and prognosis in multiple system atrophy: An analysis of 230 Japanese patients. Brain, 125, 1070-1083.

[20] Seo JH, Yong SW, Song SK, Lee JE, Sohn YH, \& Lee PH (2010) A case-control study of multiple system atrophy in Korean patients. Mov Disord, 25, 1953-1959.

[21] Jamora RD, Gupta A, Tan AK, \& Tan LC (2005) Clinical characteristics of patients with multiple system atrophy in Singapore. Ann Acad Med Singapore, 34, 553-557.

[22] Gibb WR, \& Lees AJ (1988) The relevance of the Lewy body to the pathogenesis of idiopathic Parkinson's disease. J Neurol Neurosurg Psychiatry, 51, 745-752.

[23] Forno LS (1969) Concentric hyalin intraneuronal inclusions of Lewy type in the brains of elderly persons (50 incidental cases): Relationship to parkinsonism. J Am Geriatr Soc, 17, 557-575.

[24] Dickson DW, Fujishiro H, DelleDonne A, Menke J, Ahmed Z, Klos KJ, Josephs KA, Frigerio R, Burnett M, Parisi JE, \& Ahlskog JE (2008) Evidence that incidental Lewy body disease is pre-symptomatic Parkinson's disease. Acta Neuropathol, 115, 437-444. 
[25] Wenning GK, Ben-Shlomo Y, Magalhaes M, Daniel SE, \& Quinn NP (1995) Clinicopathological study of 35 cases of multiple system atrophy. J Neurol Neurosurg Psychiatry, 58, 160-166.

[26] Jellinger KA (2007) More frequent Lewy bodies but less frequent Alzheimer-type lesions in multiple system atrophy as compared to age-matched control brains. Acta Neuropathol, 114, 299-303.

[27] Sone M, Yoshida M, Hashizume Y, Hishikawa N, \& Sobue G (2005) alpha-Synuclein-immunoreactive structure formation is enhanced in sympathetic ganglia of patients with multiple system atrophy. Acta Neuropathol, 110, 19-26.

[28] Nishie M, Mori F, Fujiwara H, Hasegawa M, Yoshimoto M, Iwatsubo $\mathrm{T}$, Takahashi $\mathrm{H}$, \& Wakabayashi $\mathrm{K}$ (2004) Accumulation of phosphorylated alpha-synuclein in the brain and peripheral ganglia of patients with multiple system atrophy. Acta Neuropathol, 107, 292298.

[29] Quinn N (1989) Multiple system atrophy-the nature of the beast. J Neurol Neurosurg Psychiatry, (Suppl) 78-89.

[30] Ahmed Z, Asi YT, Sailer A, Lees AJ, Houlden H, Revesz T, \& Holton JL (2012) The neuropathology, pathophysiology and genetics of multiple system atrophy. Neuropathol Appl Neurobiol, 38, 4-24.

[31] Spillantini MG, \& Goedert M (2000) The alphasynucleinopathies: Parkinson's disease, dementia with Lewy bodies, and multiple system atrophy. Ann N Y Acad Sci, 920, 16-27.

[32] Ozawa T, Takano H, Onodera O, Kobayashi H, Ikeuchi T, Koide R, Okuizumi K, Shimohata T, Wakabayashi K, Takahashi H, \& Tsuji S (1999) No mutation in the entire coding region of the alpha-synuclein gene in pathologically confirmed cases of multiple system atrophy. Neurosci Lett, 270, 110-112.

[33] Morris HR, Vaughan JR, Datta SR, Bandopadhyay R, Rohan De Silva HA, Schrag A, Cairns NJ, Burn D, Nath U, Lantos PL, Daniel S, Lees AJ, Quinn NP, \& Wood NW (2000) Multiple system atrophy/progressive supranuclear palsy: Alpha-Synuclein, synphilin, tau, and APOE. Neurology, 55, 1918-1920.

[34] Lincoln SJ, Ross OA, Milkovic NM, Dickson DW, Rajput A, Robinson CA, Papapetropoulos S, Mash DC, \& Farrer MJ (2007) Quantitative PCR-based screening of alpha-synuclein multiplication in multiple system atrophy. Parkinsonism Relat Disord, 13, 340-342.

[35] Langerveld AJ, Mihalko D, DeLong C, Walburn J, \& Ide CF (2007) Gene expression changes in postmortem tissue from the rostral pons of multiple system atrophy patients. Mov Disord, 22, 766-777.

[36] Ozawa T, Okuizumi K, Ikeuchi T, Wakabayashi K, Takahashi H, \& Tsuji S (2001) Analysis of the expression level of alpha-synuclein mRNA using postmortem brain samples from pathologically confirmed cases of multiple system atrophy. Acta Neuropathol, 102, 188-190.

[37] Vogt IR, Lees AJ, Evert BO, Klockgether T, Bonin M, \& Wullner U (2006) Transcriptional changes in multiple system atrophy and Parkinson's disease putamen. Exp Neurol, 199, 465-478.

[38] Ozawa T, Healy DG, Abou-Sleiman PM, Ahmadi KR, Quinn N, Lees AJ, Shaw K, Wullner U, Berciano J, Moller JC, Kamm C, Burk K, Josephs KA, Barone P, Tolosa E, Goldstein DB, Wenning G, Geser F, Holton JL, Gasser T, Revesz T, \& Wood NW (2006) The alpha-synuclein gene in multiple system atrophy. J Neurol Neurosurg Psychiatry, 77, 464-467.
[39] Ross OA, Vilarino-Guell C, Wszolek ZK, Farrer MJ, \& Dickson DW (2010) Reply to: SNCA variants are associated with increased risk of multiple system atrophy. Ann Neurol, 67, 414-415.

[40] Yun JY, Lee WW, Lee JY, Kim HJ, Park SS, \& Jeon BS (2010) SNCA variants and multiple system atrophy. Ann Neurol, 67, 554-555.

[41] Singleton AB, Farrer M, Johnson J, Singleton A, Hague S, Kachergus J, Hulihan M, Peuralinna T, Dutra A, Nussbaum R, Lincoln S, Crawley A, Hanson M, Maraganore D, Adler C, Cookson MR, Muenter M, Baptista M, Miller D, Blancato J, Hardy J, \& Gwinn-Hardy K (2003) alpha-Synuclein locus triplication causes Parkinson's disease. Science, 302, 841.

[42] Ibanez P, Bonnet AM, Debarges B, Lohmann E, Tison F, Pollak P, Agid Y, Durr A, \& Brice A (2004) Causal relation between alpha-synuclein gene duplication and familial Parkinson's disease. Lancet, 364, 1169-1171.

[43] Chartier-Harlin MC, Kachergus J, Roumier C, Mouroux V, Douay X, Lincoln S, Levecque C, Larvor L, Andrieux J, Hulihan M, Waucquier N, Defebvre L, Amouyel P, Farrer M, \& Destee A (2004) Alpha-synuclein locus duplication as a cause of familial Parkinson's disease. Lancet, 364, 1167-1169.

[44] Gwinn-Hardy K, Mehta ND, Farrer M, Maraganore D, Muenter M, Yen SH, Hardy J, \& Dickson DW (2000) Distinctive neuropathology revealed by alpha-synuclein antibodies in hereditary parkinsonism and dementia linked to chromosome 4p. Acta Neuropathol, 99, 663-672.

[45] Obi T, Nishioka K, Ross OA, Terada T, Yamazaki K, Sugiura A, Takanashi M, Mizoguchi K, Mori H, Mizuno Y, \& Hattori N (2008) Clinicopathologic study of a SNCA gene duplication patient with Parkinson disease and dementia. Neurology, 70, 238-241.

[46] Simon-Sanchez J, Hanson M, Singleton A, Hernandez D, McInerney A, Nussbaum R, Werner J, Gallardo M, Weiser R, Gwinn-Hardy K, Singleton AB, \& Clarimon J (2005) Analysis of SCA-2 and SCA-3 repeats in Parkinsonism: Evidence of SCA-2 expansion in a family with autosomal dominant Parkinson's disease. Neurosci Lett, 382, 191-194.

[47] Wilkins A, Brown JM, \& Barker RA (2004) SCA2 presenting as levodopa-responsive parkinsonism in a young patient from the United Kingdom: A case report. Mov Disord, 19, 593-595.

[48] Gwinn-Hardy K, Chen JY, Liu HC, Liu TY, Boss M, Seltzer W, Adam A, Singleton A, Koroshetz W, Waters C, Hardy J, \& Farrer M (2000) Spinocerebellar ataxia type 2 with parkinsonism in ethnic Chinese. Neurology, 55, 800-805.

[49] Furtado S, Payami H, Lockhart PJ, Hanson M, Nutt JG, Singleton AA, Singleton A, Bower J, Utti RJ, Bird TD, de la Fuente-Fernandez R, Tsuboi Y, Klimek ML, Suchowersky O, Hardy J, Calne DB, Wszolek ZK, Farrer M, Gwinn-Hardy K, \& Stoessl AJ (2004) Profile of families with parkinsonismpredominant spinocerebellar ataxia type 2 (SCA2). Mov Disord, 19, 622-629.

[50] Yeh TH, Lu CS, Chou YH, Chong CC, Wu T, Han NH, \& Chen RS (2005) Autonomic dysfunction in Machado-Joseph disease. Arch Neurol, 62, 630-636.

[51] Takiyama Y, Sakoe K, Nakano I, \& Nishizawa M (1997) Machado-Joseph disease: Cerebellar ataxia and autonomic dysfunction in a patient with the shortest known expanded allele (56 CAG repeat units) of the MJD1 gene. Neurology, 49, 604-606.

[52] Iranzo A, Munoz E, Santamaria J, Vilaseca I, Mila M, \& Tolosa E (2003) REM sleep behavior disorder and vocal cord paralysis in Machado-Joseph disease. Mov Disord, 18, 1179-1183. 
[53] D’Abreu A, Friedman J, \& Coskun J (2005) Non-movement disorder heralds symptoms of Machado-Joseph disease years before ataxia. Mov Disord, 20, 739-741.

[54] Gilman S, Sima AA, Junck L, Kluin KJ, Koeppe RA, Lohman ME, \& Little R (1996) Spinocerebellar ataxia type 1 with multiple system degeneration and glial cytoplasmic inclusions. Ann Neurol, 39, 241-255.

[55] Probst-Cousin S, Acker T, Epplen JT, Bergmann M, Plate KH, Neundorfer B, \& Heuss D (2004) Spinocerebellar ataxia type 2 with glial cell cytoplasmic inclusions. J Neurol Neurosurg Psychiatry, 75, 503-505.

[56] Berciano J, \& Ferrer I (2005) Glial cell cytoplasmic inclusions in SCA2 do not express alpha-synuclein. J Neurol, 252, 742-744.

[57] Nirenberg MJ, Libien J, Vonsattel JP, \& Fahn S (2007) Multiple system atrophy in a patient with the spinocerebellar ataxia 3 gene mutation. Mov Disord, 22, 251-254.

[58] Takano H, Cancel G, Ikeuchi T, Lorenzetti D, Mawad R, Stevanin G, Didierjean O, Durr A, Oyake M, Shimohata T, Sasaki R, Koide R, Igarashi S, Hayashi S, Takiyama Y, Nishizawa M, Tanaka H, Zoghbi H, Brice A, \& Tsuji S (1998) Close associations between prevalences of dominantly inherited spinocerebellar ataxias with CAG-repeat expansions and frequencies of large normal CAG alleles in Japanese and Caucasian populations. Am J Hum Genet, 63, 1060-1066.

[59] Cairns NJ, Atkinson PF, Kovacs T, Lees AJ, Daniel SE, \& Lantos PL (1997) Apolipoprotein E e4 allele frequency in patients with multiple system atrophy. Neurosci Lett, 221 161-164.

[60] Morris HR, Schrag A, Nath U, Burn D, Quinn NP, Daniel S, Wood NW, \& Lees AJ (2001) Effect of ApoE and tau on age of onset of progressive supranuclear palsy and multiple system atrophy. Neurosci Lett, 312, 118-120.

[61] Cho S, Kim CH, Cubells JF, Zabetian CP, Hwang DY, Kim JW, Cohen BM, Biaggioni I, Robertson D, \& Kim KS (2003) Variations in the dopamine beta-hydroxylase gene are not associated with the autonomic disorders, pure autonomic failure, or multiple system atrophy. Am J Med Genet A, 120 , 234-236

[62] Healy DG, Abou-Sleiman PM, Ozawa T, Lees AJ, Bhatia K, Ahmadi KR, Wullner U, Berciano J, Moller JC, Kamm C, Burk K, Barone P, Tolosa E, Quinn N, Goldstein DB, \& Wood NW (2004) A functional polymorphism regulating dopamine beta-hydroxylase influences against Parkinson's disease. Ann Neurol, 55, 443-446.

[63] Healy DG, Abou-Sleiman PM, Quinn N, Ahmadi KR, Ozawa T, Kamm C, Wullner U, Oertel WH, Burk K, Dupont E, Pellecchia MT, Tolosa E, Gasser T, Holton JL, Revesz T, Goldstein DB, Lees AJ, \& Wood NW (2005) UCHL-1 gene in multiple system atrophy: A haplotype tagging approach. Mov Disord, 20, 1338-1343.

[64] Yabe I, Soma H, Takei A, Fujik N, \& Sasaki H (2004) No association between FMR1 premutations and multiple system atrophy. J Neurol, 251, 1411-1412.

[65] Biancalana V, Toft M, Le Ber I, Tison F, Scherrer E, Thibodeau S, Mandel JL, Brice A, Farrer MJ, \& Durr A (2005) FMR1 premutations associated with fragile $\mathrm{X}$-associated tremor/ataxia syndrome in multiple system atrophy. Arch Neurol, 62, 962966.

[66] Garland EM, Vnencak-Jones CL, Biaggioni I, Davis TL, Montine TJ, \& Robertson D (2004) Fragile X gene premutation in multiple system atrophy. J Neurol Sci, 227, 115-118.

[67] Kamm C, Healy DG, Quinn NP, Wullner U, Moller JC, Schols L, Geser F, Burk K, Borglum AD, Pellecchia MT, Tolosa E, del Sorbo F, Nilsson C, Bandmann O, Sharma M, Mayer P, Gasteiger M, Haworth A, Ozawa T, Lees AJ, Short J, Giunti P, Holinski-Feder E, Illig T, Wichmann HE, Wenning GK, Wood NW, \& Gasser T (2005) The fragile $\mathrm{X}$ tremor ataxia syndrome in the differential diagnosis of multiple system atrophy: Data from the EMSA Study Group. Brain, 128, 1855-1860.

[68] Lu CS, Chang HC, Weng YH, Chen RS, Bonifati V, \& WuChou YH (2008) Analysis of the LRRK2 Gly2385Arg variant in primary dystonia and multiple system atrophy in Taiwan. Parkinsonism Relat Disord, 14, 393-396.

[69] Hernandez D, Paisan Ruiz C, Crawley A, Malkani R, Werner J, Gwinn-Hardy K, Dickson D, Wavrant Devrieze F, Hardy J, \& Singleton A (2005) The dardarin G 2019S mutation is a common cause of Parkinson's disease but not other neurodegenerative diseases. Neurosci Lett, 389, 137-139.

[70] Aharon-Peretz J, Rosenbaum H, \& Gershoni-Baruch R (2004) Mutations in the glucocerebrosidase gene and Parkinson's disease in Ashkenazi Jews. N Engl J Med, 351, 1972-1977.

[71] Mata IF, Samii A, Schneer SH, Roberts JW, Griffith A, Leis BC, Schellenberg GD, Sidransky E, Bird TD, Leverenz JB, Tsuang D, \& Zabetian CP (2008) Glucocerebrosidase gene mutations: A risk factor for Lewy body disorders. Arch Neurol, 65, 379-382.

[72] Bras J, Paisan-Ruiz C, Guerreiro R, Ribeiro MH, Morgadinho A, Januario C, Sidransky E, Oliveira C, \& Singleton A (2009) Complete screening for glucocerebrosidase mutations in Parkinson disease patients from Portugal. Neurobiol Aging, 30, 1515-1517.

[73] Neumann J, Bras J, Deas E, O’Sullivan SS, Parkkinen L, Lachmann RH, Li A, Holton J, Guerreiro R, Paudel R, Segarane B, Singleton A, Lees A, Hardy J, Houlden H, Revesz T, \& Wood NW (2009) Glucocerebrosidase mutations in clinical and pathologically proven Parkinson's disease. Brain, 132, 1783-1794.

[74] Sidransky E, Nalls MA, Aasly JO, Aharon-Peretz J, Annesi G, Barbosa ER, Bar-Shira A, Berg D, Bras J, Brice A, Chen CM, Clark LN, Condroyer C, De Marco EV, Durr A, Eblan MJ, Fahn S, Farrer MJ, Fung HC, Gan-Or Z, Gasser T, Gershoni-Baruch R, Giladi N, Griffith A, Gurevich T, Januario C, Kropp P, Lang AE, Lee-Chen GJ, Lesage S, Marder K, Mata IF, Mirelman A, Mitsui J, Mizuta I, Nicoletti G, Oliveira C, Ottman R, Orr-Urtreger A, Pereira LV, Quattrone A, Rogaeva E, Rolfs A, Rosenbaum H, Rozenberg R, Samii A, Samaddar T, Schulte C, Sharma M, Singleton A, Spitz M, Tan EK, Tayebi N, Toda T, Troiano AR, Tsuji S, Wittstock M, Wolfsberg TG, Wu YR, Zabetian CP, Zhao Y, \& Ziegler SG (2009) Multicenter analysis of glucocerebrosidase mutations in Parkinson's disease. N Engl J Med, 361, 1651-1661.

[75] Mitsui J, Mizuta I, Toyoda A, Ashida R, Takahashi Y, Goto J, Fukuda Y, Date H, Iwata A, Yamamoto M, Hattori N, Murata M, Toda T, \& Tsuji S (2009) Mutations for Gaucher disease confer high susceptibility to Parkinson disease. Arch Neurol, 66, 571-576

[76] Goker-Alpan O, Giasson BI, Eblan MJ, Nguyen J, Hurtig HI, Lee VM, Trojanowski JQ, \& Sidransky E (2006) Glucocerebrosidase mutations are an important risk factor for Lewy body disorders. Neurology, 67, 908-910.

[77] Segarane B, Li A, Paudel R, Scholz S, Neumann J, Lees A, Revesz T, Hardy J, Mathias CJ, Wood NW, Holton J, \& Houlden H (2009) Glucocerebrosidase mutations in 108 neuropathologically confirmed cases of multiple system atrophy. Neurology, 72, 1185-1186.

[78] Jamrozik Z, Lugowska A, Slawek J, \& Kwiecinski H (2010) Glucocerebrosidase mutations p.L444P and p.N370S are not 
associated with multisystem atrophy, progressive supranuclear palsy and corticobasal degeneration in Polish patients. J Neurol, 257, 459-460.

[79] Brooks JA, Houlden H, Melchers A, Islam AJ, Ding J, Li A, Paudel R, Revesz T, Holton JL, Wood N, Lees A, Singleton AB, \& Scholz SW (2010) Mutational analysis of parkin and PINK1 in multiple system atrophy. Neurobiol Aging, 32, 548 e545-e547.

[80] Vilarino-Guell C, Soto-Ortolaza AI, Rajput A, Mash DC, Papapetropoulos S, Pahwa R, Lyons KE, Uitti RJ, Wszolek ZK, Dickson DW, Farrer MJ, \& Ross OA (2011) MAPT H1 haplotype is a risk factor for essential tremor and multiple system atrophy. Neurology, 76, 670-672.

[81] Conrad C, Amano N, Andreadis A, Xia Y, Namekataf K, Oyama F, Ikeda K, Wakabayashi K, Takahashi H, Thal LJ, Katzman R, Shackelford DA, Matsushita M, Masliah E, \& Sawa A (1998) Differences in a dinucleotide repeat polymorphism in the tau gene between Caucasian and Japanese populations: Implication for progressive supranuclear palsy. Neurosci Lett, 250, 135-137.

[82] Combarros O, Infante J, Llorca J, \& Berciano J (2003) Interleukin-1A (-889) genetic polymorphism increases the risk of multiple system atrophy. Mov Disord, 18, 13851386.

[83] Nishimura M, Kawakami H, Komure O, Maruyama H, Morino H, Izumi Y, Nakamura S, Kaji R, \& Kuno S (2002) Contribution of the interleukin-1beta gene polymorphism in multiple system atrophy. Mov Disord, 17, 808-811.

[84] Infante J, Llorca J, Berciano J, \& Combarros O (2005) Interleukin-8, intercellular adhesion molecule-1 and tumour necrosis factor-alpha gene polymorphisms and the risk for multiple system atrophy. J Neurol Sci, 228, 11-13.

[85] Furiya Y, Hirano M, Kurumatani N, Nakamuro T, Matsumura R, Futamura N, \& Ueno S (2005) Alpha-1-antichymotrypsin gene polymorphism and susceptibility to multiple system atrophy (MSA). Brain Res Mol Brain Res, 138, 178-181.

[86] Nishimura M, Kuno S, Kaji R, \& Kawakami H (2005) Influence of a tumor necrosis factor gene polymorphism in Japanese patients with multiple system atrophy. Neurosci Lett, 374, 218-221.
[87] Muangpaisan W, Hori H, \& Brayne C (2009) Systematic review of the prevalence and incidence of Parkinson's disease in Asia. J Epidemiol, 19, 281-293.

[88] Winter Y, Bezdolnyy Y, Katunina E, Avakjan G, Reese JP, Klotsche J, Oertel WH, Dodel R, \& Gusev E (2010) Incidence of Parkinson's disease and atypical parkinsonism: Russian population-based study. Mov Disord, 25, 349-356.

[89] Elbaz A, Clavel J, Rathouz PJ, Moisan F, Galanaud JP, Delemotte B, Alperovitch A, \& Tzourio C (2009) Professional exposure to pesticides and Parkinson disease. Ann Neurol, 66, 494-504.

[90] Weisskopf MG, Knekt P, O'Reilly EJ, Lyytinen J, Reunanen A, Laden F, Altshul L, \& Ascherio A (2010) Persistent organochlorine pesticides in serum and risk of Parkinson disease. Neurology, 74, 1055-1061.

[91] Vidal JS, Vidailhet M, Elbaz A, Derkinderen P, Tzourio C, \& Alperovitch A (2008) Risk factors of multiple system atrophy: A case-control study in French patients. Mov Disord, 23, 797 803.

[92] Nee LE, Gomez MR, Dambrosia J, Bale S, Eldridge R, \& Polinsky RJ (1991) Environmental-occupational risk factors and familial associations in multiple system atrophy: A preliminary investigation. Clin Auton Res, 1, 9-13.

[93] Vanacore N, Bonifati V, Fabbrini G, Colosimo C, De Michele G, Marconi R, Nicholl D, Locuratolo N, Talarico G, Romano S, Stocchi F, Bonuccelli U, De Mari M, Vieregge P, \& Meco G (2001) Epidemiology of multiple system atrophy. ESGAP Consortium. European Study Group on Atypical Parkinsonisms. Neurol Sci, 22, 97-99.

[94] Kim JM, \& Jeon BS (2009) Survivors from beta-fluoroethyl acetate poisoning show a selective cerebellar syndrome. $J$ Neurol Neurosurg Psychiatry, 80, 528-532.

[95] Brighina L, Frigerio R, Schneider NK, Lesnick TG, de Andrade M, Cunningham JM, Farrer MJ, Lincoln SJ, Checkoway H, Rocca WA, \& Maraganore DM (2008) Alphasynuclein, pesticides, and Parkinson disease: A case-control study. Neurology, 70, 1461-1469. 